\title{
Hubungan Karekteristik Perawat pada Program Preceptorship terhadap Proses Adaptasi Perawat Baru
}

\author{
Sr. Sofia Gusnia, Nurmaida Saragih CB \\ Poltekkes Kemenkes Bandung \\ Email:sofie_cb@yahoo.com
}

\begin{abstract}
Abstrak
Perawat baru adalah perawat yang memasuki pengalaman baru yang sebelumnya tidak dialami. Transisi shock muncul sebagai pengalaman dari peran yang sudah dikenal yaitu sebagai mahasiswa ke peran yang belum dialami yaitu sebagai perawat pelaksana profesional. Program pembimbingan perawat baru sangat penting untuk mempercepat proses adaptasi. Program preceptorship adalah pendekatan efektif dalam pengajaran klinik, merupakan bagian integral dari orientasi perawat baru. Angka turnover perawat baru tiga tahun terakhir (2007-2009) di RS A adalah antara 37\%-59\%, di RS B dalam tiga tahun ini (2008-2010) adalah antara $2,6 \%-14,7 \%$. Di RS C dalam dua tahun ini (2009-2010) adalah antara $14,6 \%-27 \%$. Penelitian ini bertujuan mengetahui hubungan program preceptorship dan karekteristik perawat dengan proses adaptasi perawat baru. Desain penelitian deskriptif korelasi dengan pendekatan potong lintang. Sampel penelitian 100 perawat baru. Instrumen digunakan adalah kuesioner. Hasil penelitian menunjukkan bahwa variabel karekteristik perawat yang meliputi lama kerja $(p=0.004)$, konflik $(p=0.000)$, strategi koping $(p=0.003)$, self efficacy $(p=0.000)$, dan program preceptorship $(p=0.002)$ berhubungan dengan proses adaptasi. Faktor dominan yang berhubungan dengan proses adaptasi adalah self efficacy dengan nilai odds ratio (OR) 6,68. Program preceptorship dan karekteristik perawat self efficacy $(\mathrm{p}=0.000)$, konflik $(\mathrm{p}=0.003)$, dan lama kerja $(\mathrm{p}=0.003)$ berhubungan dengan proses adaptasi perawat baru. Manajer keperawatan perlu menyediakan preceptor yang kompeten yang menjadi role model untuk meningkatkan self efficacy perawat baru sehingga membantu proses adaptasi.
\end{abstract}

Kata kunci: Karekteristik perawat, program preceptorship, proses adaptasi

\section{The Correlation of Nurses's Characteristics and The Preceptorship Program with Novice Nurse}

\begin{abstract}
Novice nurse is a nurse who have a new experience that had not previously experienced. Transition shock' experience emerged cause of changing role from the well-known role as a student into the unfamiliar role as professional nurses. Preceptorship program for the novice nurse is very important to speed up the process of adaptation. Preceptorship program is an effective approach in clinical teaching and an integral part of the orientation for novice nurses. Turnover rate of novice nurses in last 3 years (2007-009) in the Hospital A is between 37\%-59\%, in Hospital B in 3 years (2008-2010) is among 2.6\%-14.7\%. While in the Hospital C within 2 years (2009-2010) is among the $14,6 \%-27 \%$. The research aims to determine the correlation of preceptorship programs and the characteristics of nurses with the adaptation process of novice nurses. The study design used a descriptive correlation with the crosssectional approach. The samples were 100 novice nurses. The instrument used was a questionnaire. The results show that the variables of nurses' characteristics which includes length of working $(p=0.004)$, conflict $(p=0.000)$, coping strategies $(p=0.003)$, self-efficacy $(p=0.000)$ and preceptorship program $(p=0.002)$ are correlated with the process of adaptation. Dominant factor related to the adaptation process is self-efficacy with the OR 6.68. Preceptorship programs and the characteristics of nurses self efficacy $(p=0.000)$, conflict $(p=0.003)$, and length of working $(\mathrm{p}=$ 0.003 ) correlated with the process of adaptation of the novice nurses. Nursing managers need to provide a competent preceptor who be able to become a role model for improving self efficacy of novice nurses to assist their adaptation.
\end{abstract}

Key words: Nurse characteristics, preceptorship program, process of adaptation 
Sr Sofia Gusnia: Hubungan Karekteristik Perawat pada Program Preceptorship

\section{Pendahuluan}

Pelayanan keperawatan merupakan pelayanan kesehatan terbesar di rumah sakit yaitu sekitar 40\%-60\% (Gillies, 1994). Keberhasilan perawatan dalam memberikan pelayanan dikatakan Gillies (1994) sebagai cerminan utama kualitas pelayanan di rumah sakit secara menyeluruh. Hal tersebut didukung oleh Aditama (2003) yang menyatakan bahwa pelayanan keperawatan merupakan pemberi pelayanan 24 jam secara terus menerus, sehingga berperan penting dalam upaya menjaga mutu pelayanan kesehatan.

Perawat baru yang memasuki lingkungan kerja baru akan menghadapi berbagai masalah. Beberapa bulan pertama merupakan masa yang penuh tantangan dan dapat menimbulkan stres bagi perawat baru (Chang \& Hancock, 2003). Transisi shock muncul sebagai pengalaman dari peran yang sudah dikenal yaitu sebagai mahasiswa ke peran yang belum familier yaitu sebagai perawat pelaksana profesional (Duchscher, 2008). Proses pengenalan lingkungan kerja merupakan hal penting bagi perawat baru, hal tesebut akan mempermudah perawat baru menyesuaikan diri dalam melaksanakan tugas dan fungsi yang dibebankan kepada perawat baru.

Pendekatan yang paling umum diambil oleh organisasi kesehatan dalammendampingi perawat baru adalah program preceptorship. Program preceptorship menggunakan preceptor untuk menolong perawat baru selama masa orientasi. Preceptor adalah perawat berpengalaman yang memberikan dukungan emosional dan merupakan model peran klinis yang kuat bagi perawat baru (Marquis \& Houston, 2010). Kebutuhan akan preceptor merupakan persyaratan dari konsil keperawatan untuk meningkatkan asuhan keperawatan, menurunkan tingkat kecemasan perawat baru, serta tanggung jawab akan diberikan sesuai dengan kapasitas perawat baru (Rose, 2007).

Allanach dan Jennings (2006) dalam penelitiannya mengatakan bahwa program preceptorship tetap penting dan merupakan intervensi yang dibutuhkan untuk memfasilitasi dan membuat peran perawat terintegrasi. Lama program preceptorship itu bervariasi mulai dari delapan minggu sampai dengan satu tahun (Floyd, 2003; Salt, Cummings, \& Profetto-McGrath, 2008).

Eley (2010) dalam penelitiannya mengatakan bahwa hubungan antara preceptor dan perawat baru tidak dapat diabaikan. Preceptor bertanggung dalam menolong perawat baru untuk meningkatkan potensi mereka. Saling menghargai dan mendukung harus terjadi dalam hubungan preceptor dan perawat baru.

Beecroft, Dorey, dan Wenten (2008) dalam penelitiannya mengatakan bahwa karekteristik perawat memengaruhi keluar tidaknya perawat dalam masa orientasi. Karekteristik tersebut meliputi usia, tingkat pendidikan, masa kerja, konflik atau stres (reality shock), dan strategi koping. Menurut Cooper dan Palmer (2000), jenis kelamin juga berpengaruh dalam program preceptorship dan proses adaptasi. Penelitian tersebut membahas pula mengenai Self efficacy (kemantapan diri) yang merupakan karekteristik pribadi pendatang baru yang penting bagi suatu organisasi. Self efficacy adalah keyakinan seseorang terhadap kemampuannya untuk menyelesaikan tugas yang dipercayakan kepadanya (Peterson, 2009).

Turnover perawat baru di rumah sakit swasta A dalam tiga tahun terakhir (20072009 ) adalah antara $37 \%-59 \%$, di rumah sakit swasta B dalam tiga tahun ini (2008-2010) adalah antara $2,6 \%-14,7 \%$, dan rumah sakit swasta C dalam dua tahun ini (2009-2010) adalah antara $14,6 \%-27 \%$.

\section{Metode Penelitian}

Desain penelitian yang digunakan deskriptif korelatif dengan pendekatan potong lintang. Penelitian ini menggunakan kuesioner. Kuesioner A untuk mengukur karekteristik perawat (usia, jenis kelamin, tingkat pendidikan, masa kerja, konflik, strategi koping, dan self efficacy) dimodifikasi dari kuesioner Peterson (2009), instrumen The Ways of Coping Revised (WOCR) Folkman dan Lazarus (1994), dan dari teori yang ada. Kuesioner B mengukur program preceptorship dikembangkan peneliti berdasarkan tinjauan pustaka yang ada. Responden penelitian adalah 100 perawat baru dengan teknik total sampling. 
Sr Sofia Gusnia: Hubungan Karekteristik Perawat pada Program Preceptorship

\section{Hasil Penelitian}

Hasil penelitian ini menjawab seluruh tujuan penelitian yang menggambarkan tentang program preceptorship (orientasi, pembelajaran di kelas, pembimbingan, rotasi, dan evaluasi), karekteristik perawat (usia, jenis kelamin, tingkat pendidikan, lama kerja, konflik atau stres, strategi koping, dan self efficacy), hubungan program preceptorship, dan karekteristik perawat dengan proses adaptasi perawat baru, serta faktor yang paling berpengaruh terhadap proses adaptasi. Rata-rata usia perawat baru adalah 23,46 tahun dan rata-rata lama kerja adalah 7,38 bulan. Mayoritas perawat baru berjenis kelamin perempuan (94\%) dengan tingkat pendidikan mayoritas adalah D3 keperawatan (91\%).

Karekteristik perawat komponen konflik/ stres lebih dari sebagian perawat baru memersepsikan mengalami konflik (58\%), 64\% memersepsikan strategi koping kurang baik, dan lebih dari sebagian memersepsikan self efficacy kurang baik (56\%). Program preceptorship dipersepsikanbaik oleh perawat baru (53\%) dengan komponen orientasi dipersepsikan baik $(86 \%)$, pembelajaran dikelas $(55 \%)$, pembimbingan dan rotasi $(50 \%)$, dan evaluasi (88\%). Proses adaptasi dipersepsikan baik oleh perawat baru (54\%).

Hasil analisis bivariat menunjukkan bahwa program preceptorship berhubungan dengan proses adaptasi perawat baru $(p=0.002)$ dengan rincian sebagai berikut: tidak ada hubungan antara orientasi dengan proses adaptasi perawat baru $(p=0,159)$, tidak ada hubungan antara pembelajaran di kelas dengan proses adaptasi perawat baru $(p=0.053)$, tidak ada hubungan antara pembimbingan klinik dengan proses adaptasi perawat baru $(p=0.071)$, tidak ada hubungan antara rotasi dengan proses adaptasi perawat baru $(p=0.316)$, dan ada hubungan antara evaluasi dengan proses adaptasi perawat baru $(p=0.011)$. Sementara karekteristik perawat yang berhubungan dengan proses adaptasi adalahlamakerja $(p=0.004), \operatorname{konflik}(p=0.000)$, strategi koping $(p=0.003)$, dan self efficacy $(p=0.000)$. Analisis multivariat menunjukkan bahwa komponen yang berhubungan dengan proses adaptasi adalah lama kerja, konflik, dan self efficacy. Paling dominan berpengaruh terhadap proses adaptasi adalah self efficacy karena memiliki nilai $\mathrm{p}=0,000$ dengan nilai OR 6,678 yang berarti perawat baru dengan self efficacy baik berpeluang sebesar 6,678 kali berproses adaptasi lebih baik dibanding dengan perawat baru yang memersepsikan self efficacy kurang baik (CI: 2,323-19,194).

\section{Pembahasan}

Terdapat hubungan antara lama kerja dengan proses adaptasi perawat baru. Rata-rata lama kerja perawat baru adalah 7,38 bulan. Hasil analisis bivariat menunjukkan bahwa ratarata lama kerja perawat baru yang kurang baik dalam proses adaptasinya adalah 8,09 bulan. Hasil ini menunjukan bahwa semakin lama kerja seorang perawat baru semakin mencegah perawat itu untuk dapat beradaptasi dengan baik.

Pendapat di atas kurang senada dengan pendapat Clark dan Holmes (2007) mengatakan bahwa dalam enam bulan setelah perawat baru diterima, sebagian besar memperoleh kepercayaan diri dan merasa siap melaksanakan praktek secara mandiri. Hasil penelitian ini menunjukkan perawat baru yang proses adaptasinya kurang baik namun lama kerjanya lebih lama dibanding mereka yang proses adaptasinya baik. Perbedaan ini dapat terjadi karena semakin lama perawat baru bekerja semakin banyak tanggung jawab yang dilimpahkan, semakin dituntut untuk mandiri, dan memengaruhi dalam proses adaptasi.

Hasil penelitian ini berbeda dengan teori bahwa pekerjaan yang ditunjukkan oleh setiap individu dipengaruhi oleh pengalaman dalam kurun waktu tertentu. Semakin lama masa kerja individu dalam organisasi, maka pengalaman kerja yang didapatkan semakin bertambah dan mudah untuk menyesuaikan diri dengan lingkungan kerjanya. Hasil penelitian menggambarkan bahwa semakin lama perawat baru bekerja semakin proses adaptasinya kurang baik disebabkan beban kerja dan tanggung jawab yang diberikan cukup tinggi. Adaptasi perawat baru yang kurang baik juga dapat disebabkan karena ketenagaan yang ada mungkin kurang sebanding dengan jumlah dan klasifikasi pasien. Perawat baru suatu waktu tertentu 
Sr Sofia Gusnia: Hubungan Karekteristik Perawat pada Program Preceptorship

kemungkinan sudah diperhitungkan sebagai tenaga inti sehingga antara harapan perawat baru dan kenyataan dilapangan dapat membuat perawat baru merasa kecewa dan jenuh. Meskipun demikian, tidak semua perawat baru beradaptasi kurang baik. Proses adaptasi yang baik dipengaruhi oleh motivasi dan komitmen tinggi dalam pelayanan sebagai perawat.

Perbedaan signifikan terlihat pada ratarata lama kerja antara perawat baru yang proses adaptasinya baik dengan perawat baru dengan proses adaptasi yang kurang baik (Wang, Sermsri, Sirisook, dan Sawangdee ,2003). Perawat yang mempunyai masa kerja lama, lebih mudah mengerti dan beradaptasi dengan lingkungan kerjanya. Semakin lama masa kerja perawat, pengalaman perawat semakin banyak, lebih mudah dalam memahami pekerjaan, serta dapat beradaptasi dalam menghadapi situasi di tempat kerja (work place). Sopiah (2008) menyatakan bahwa semakin lama seorang karyawan bekerja, semakin rendah keinginan karyawan untuk meninggalkan pekerjaannya. Kondisi ini dapat diasumsikan bahwa perawat tersebut telah mampu beradaptasi dan memiliki motivasi yang tinggi.

Pada penelitian ini ada hubungan antara konflik dengan proses adaptasi perawat baru. Hasil analisis univariat menunjukkan bahwa $58 \%$ perawat baru memersepsikan mengalami konflik. Artinya proporsi perawat baru yang mengalami konflik lebih besar dibanding perawat yang tidak mengalami konflik. Sejalan dengan pendapat Kramer dalam Marquis dan Houston (2010) ketakutan dan kesulitan khusus dalam beradaptasi dengan lingkungan kerja adalah hal yang umum dialami perawat baru dan ketakutan ini adalah sebagai reality shock karena terjadi sebagai akibat konflik antara ekspektasi perawat baru terhadap peran keperawatan dan kenyataan peran sesungguhnya di lapangan kerja. Hasil analisis diperoleh nilai $\mathrm{OR}=6,460$, artinya perawat baru yang tidak mengalami konflik mempunyai peluang 6,460 kali proses adaptasi baik dibanding perawat baru yang mengalami konflik.

Sebaran item pernyataan mengenai konflik atau stres menunjukan 17 perawat baru memersepsikan sering dan 66 orang perawat baru memersepsikan kadang-kadang mengalami ketakutan akan terjadi kesalahan dalam memberikan asuhan keperawatan kepada pasien. Hal ini sesuai dengan penelitian dari Gerrish (2000) yang mengatakan bahwa perawat baru melaporkan suatu ketakutan akan membuat kesalahan dan ketakutan apabila dilihat sebagai seseorang yang tidak kompeten atau bodoh.

Sebanyak sebelas orang perawat baru memersepsikan sering dan 62 orang memersepsikan kadang-kadang mengalami kesulitan mendapatkan kesempatan untuk mengungkapkan permasalahan kepada pembimbing. Hal ini sejalan dengan Health and Safety Executive (2004) bahwa penyebab utama stres adalah beban kerja, target waktu pekerjaan, kurangnya dukungan, dan adanya perasaan terancam di tempat kerja. Perawat baru yang mengalami kesulitan dalam mendapatkan kesempatan untuk mengungkapkan permasalahannya mungkin disebabkan oleh beban kerja dari pembimbing yang tinggi sehingga tidak ada waktu untuk mendengarkan perawat baru di samping perawat baru merasa segan untuk mengatakan apa yang dialami.

Mamchur dan Myrick (2003) mengatakan bahwa koordinator dari program preceptorship penting untuk mengenali konflik yang mungkin timbul antara preceptor dan preceptee. Konflik antara manusia mempunyai banyak penyebab. Sumber utama dari konflik dan stres pada pekerjaan berhubungan dengan tempat bekerja serta konflik ini juga dapat berasal dari situasi dimana seseorang harus melakukan pemilihan antara dua tuntutan atau harapan yang saling bersaing (Dubrin \& Geerinck, 2009). Saling mempertahankan informasi secara terbuka sangat penting antara preceptor dan preceptee. Hal ini senada dengan apa yang dikatakan oleh Myrick dan Yonge (2005) bahwa pengalaman preceptorship juga dapat menyebabkan stres pada preceptee dan dapat mengarah pada kekecewaan terhadap profesi perawat apabila antara preceptor dan preceptee tidak cocok. Tanggung jawab dan tanggung gugat mereka sebagai perawat baru untuk merawat pasien juga membuat mereka stres (Amos, 2001; Gerrish, 2000; O'Shea \& Kelly, 2007).

Terdapat hubungan antara strategi koping dengan proses adaptasi perawat baru. 
Sr Sofia Gusnia: Hubungan Karekteristik Perawat pada Program Preceptorship

Perawat baru memersepsikan strategi koping kurang baik sebanyak 64\%. Hasil analisis menunjukkan nilai $\mathrm{OR}=4,111$ berarti perawat baru yang memersepsikan strategi kopingnya baik mempunyai peluang 4,111 kali untuk proses adaptasi baik dibanding perawat baru yang memersepsikan strategi kopingnya kurang baik.

Folkman dan Lazarus (1994) mengatakan strategi koping adalah cara yang digunakan oleh seseorang dalam menghadapi stresor. Adapun cara-cara yang digunakan seseorang dalam mengatasi stresor meliputi konfrontasi, menjauh, kontrol diri, mencari dukungan sosial, menerima tanggung jawab, melarikan diri atau menghindar, penyelesaian masalah terencana, dan penilaian secara positif.

Terdapat 64 perawat baru yang memersepsikan kadang-kadang melibatkan diri dalam penyelesaian suatu masalah di tempat kerja. Hasil analisis menunjukan bahwa perawat baru berusaha untuk menghindar dari permasalahan yang ada di tempat kerjanya. Hal ini sejalan dengan yang diungkapkan oleh Dubrin dan Geerinck (2009) bahwa salah satu gaya dari mengatasi konflik adalah menghindari permasalahan. Orang yang menghindar adalah kombinasi dari seseorang yang tidak kooperatif dan tidak asertif.

Perawat baru perlu mengenali, memahami, dan mempraktekkan berbagai macam strategi dalam mengatasi permasalahan yang dihadapi sehubungan dengan peran baru sebagai perawat sehingga dapat menjalankan tugasnya dengan baik.

Hasil penelitian ini menunjukan adanya hubungan antara strategi koping dengan proses adaptasi perawat baru. Hasil analisis menunjukkan nilai $\mathrm{OR}=4,111$ artinya perawat baru yang memersepsikan strategi kopingnya baik mempunyai peluang 4,111 kali untuk proses adaptasi baik dibanding perawat baru yang memersepsikan strategi kopingnya kurang baik. Peluang untuk dapat beradaptasi dengan baik adalah 4,1 kali menunjukan bahwa strategi koping yang baik mempunyai peluang 4,1 kali untuk proses adaptasi yang baik

Terdapat hubungan antara self efficacy dengan proses adaptasi perawat baru.
Sebanyak 56\% perawat baru memersepsikan self efficacy kurang baik artinya perawat baru kurang percaya diri dengan kemampuannya. Dari nilai $\mathrm{OR}=7,573$ yang diperoleh artinya perawat baru yang memersepsikan self efficacy baik mempunyai peluang 7,573 kali untuk proses adaptasi baik dibanding yang memersepsikan self efficacy kurang baik.

Dari sebaran item pernyataan kuesioner mengenai self efficacy terdapat 28 orang (28\%) perawat baru memersepsikan kadang merasa percaya diri dengan kemampuannya. Sebanyak 19 orang (19\%) perawat baru mempersepsikan penampilan kerjanya kadang baik, 15 orang (15\%) perawat baru kadang bangga dengan keterampilan yang dimiliki. Sebanyak 42 orang (42\%) perawat baru memersepsikan kadang merasa terancam ketika perawat lain menyaksikan pekerjaannya. Dapat disimpulkan bahwa perawat baru kurang yakin atau mantap akan kemampuan yang dimilikinya. Persepsi self efficacy akan meningkat seiring dengan pencapaian kinerja yang sukses dan mencapai hasil yang diharapkan. Perawat baru ditemukan merasa tidak adekuat dan tidak kompeten selama tahun pertama melakukan praktek. Seringkali dilaporkan bahwa mereka tidak memiliki keterampilan dan pengetahuan yang dipersyaratkan bagi mereka (Casey, Fink, Krugman, \& Propst, 2004; Clark \& Holmes, 2007).

Self efficacy adalah keyakinan atau kemantapan diri akan kemampuannya dalam melaksanakan tugas yang dipercayakan kepada perawat baru. Berbagai studi telah menunjukkan bahwa perawat baru dengan rasa percaya diri yang tinggi cenderung untuk memiliki kinerja baik. Menumbuhkan percaya diri menjadi penting dalam karir. Perawat baru dengan percaya diri yang baik akan menetapkan tujuan yang tinggi terhadap dirinya. Implikasi langsung dari self efficacy adalah orang tersebut berpikir mereka dapat mengerjakan tugas dengan baik (Dubrin \& Geerinck, 2009).

Clark dan Holmes (2007) berpendapat bahwa dalam enam bulan setelah perawat baru diterima, sebagian besar memperoleh kepercayaan diri dan merasa bahwa mereka siap melaksanakan praktek secara mandiri. Salah satu sumber dari kepercayaan diri 
Sr Sofia Gusnia: Hubungan Karekteristik Perawat pada Program Preceptorship

menurut penelitian Hollenbeck dan Hall (2004) adalah dari sumber pertama yaitu pengalaman nyata atau hal yang telah dikerjakan, telah menyelesaikan suatu pekerjaan sebelumnya adalah cara yang paling ampuh untuk membangun kepercayaan diri. Sumber yang kedua yaitu cara modeling atau belajar dari pengalaman orang lain.

Perawat baru dapat belajar untuk membangun kepercayaan diri dari contoh yang diberikan oleh pembimbing klinik yang mendampingi. Kepercayaan diri dapat juga dibangun perawat baru dari sumber persuasi sosial atau proses peneguhan dari orang lain. Jika pembimbing klinik meyakinkan perawat baru bahwa mereka dapat melakukan suatu tugas maka perawat baru akan sering menerima dorongan besar dalam self efficacy untuk selalu mencoba melakukan tugas. Jika peneguhan ini disertai dengan pembimbingan bagaimana mengerjakan tugas dengan baik makakepercayaan diri akan diperoleh semakin tinggi. Peran dari seorang pembimbing klinik sangat besar dalam meningkatkan keyakinan diri perawat baru.

Secara umum didapatkan hasil bahwa ada hubungan antara program preceptorship dengan proses adaptasi perawat baru dengan nilai $p=0.002$ walaupun program preceptorship yang meliputi orientasi, pembelajaran di kelas, pembimbingan klinik, dan rotasi tidak memiliki hubungan dengan proses adaptasi perawat. Terdapat hubungan antara evaluasi dengan proses adaptasi perawat baru. Hasil analisis univariat menunjukkan sebagian kecil perawat baru memersepsikan evaluasi kurang baik. Hasil analisis diperoleh nilai $\mathrm{OR}=7,222$, artinya perawat baru yang memersepsikan evaluasi baik mempunyai peluang 7,222 kali dibanding perawat baru yang memersepsikan evaluasi kurang baik. Peluang ini menunjukkan bahwa evaluasi berpengaruh terhadap proses adaptasi.

Dari sebaran item pernyataan tentang evaluasi diperoleh tiga perawat baru memersepsikan tidak setuju presentasi kasus yang ditugaskan memacu untuk proses belajar, sedangkan delapan orang memersepsikan setuju merasa terganggu dengan adanya penilaian secara lisan terhadap kinerja perawat baru. Melihat kondisi yang dialami oleh perawat baru ini menjadi sangat penting apa yang diungkapkan oleh DEST (2001) dalam penelitian O'Brien-Pallas, Duffield, dan Hayes (2006) bahwa feedback positif dan konstruktif menjadi faktor yang signifikan memengaruhi pengalaman perawat baru dalam masa orientasi.

Terdapat 85 perawat baru memersepsikan setuju dan enam orang sangat setuju kecewa dengan sistem evaluasi yang ada karena tidak sesuai dengan kinerja perawat baru. Dumas, Villeneuve, dan Chevrier (2000) dalam penelitiannya menyatakan bahwa para preceptor mengalami kesulitan dalam mengevaluasi perawat baru yang telah pindah atau rotasi ke ruangan lain. Hal tersebut dapat menjadi salah satu penyebab perawat baru kecewa dengan evaluasi yang dilakukan terhadap kinerja mereka. Kemungkinan lain adalah bahwa diawal program preceptorship, preceptor dan preceptee kurang menyadari standar dan harapan akan evaluasi.

Neary (2001) dalam Myrick dan Yonge (2005) berpendapat evaluasi kinerja klinik perawat baru merupakan suatu pokok pembicaraan bagi para preceptor. Tool atau alat dari evaluasi perawat baru belum ada yang terstandar. Preceptor menggunakan tool yang bervariasi. Evaluasi program pelaksanaan dapat dilakukan secara harian, pada pertengahan, atau di bagian akhir dari program. Evaluasi dapat dilakukan secara formal yang mencakup kompetensi (sikap, keterampilan, dan pengetahuan). Evaluasi secara informal dilakukan dengan memberikan umpan balik secara verbal.

Hasil analisis multivariat menunjukan variabel yang berhubungan dengan proses adaptasi perawat baru adalah lama kerja, self efficacy, dan konflik. Variabel dominan berpengaruh terhadap proses adaptasi perawat baru adalah self efficacy dengan nilai OR paling besar yaitu 6,68. Maka bila perawat baru kurang memiliki kepercayaan atau kemantapan diri akan kemampuannya dalam bekerja sebagai perawat pelaksana maka dapat menghambat dalam proses adaptasi.

\section{Simpulan}

Hasil penelitian ini menunjukkan bahwa 
Sr Sofia Gusnia: Hubungan Karekteristik Perawat pada Program Preceptorship

manajer keperawatan perlu menyediakan preceptor yang menjadi role model untuk meningkatkan self efficacy perawat baru guna membantu proses adaptasi dan menciptakan rasa aman serta mengurangi stres atau konflik selama masa transisi perawat baru.

\section{Daftar Pustaka}

Aditama,T.J.(2003).Manajemenadministrasi rumah sakit. (Edisi kedua). Jakarta: UI.

Allanach, B. C., \& Jennings, B.M. (2006). Evaluating the effects of a nurse preceptorship programme. Journal of Advanced Nursing, $15(1)$.

Amos, D. (2001). An evaluation of staff nurse role transition. Nursing Standard, 16(3), 3641.

Beecroft, P. C., Dorey, F., \& Wenten, M. (2008). Turnover intention in new graduate nurses: A multivariate analysis. Journal of advanced nursing, 62(1), 42-52.

Casey, K. M. S., Fink, R., Krugman, M. \& Propst, J. (2004). The graduate nurse experience. Journal of Nursing Administration, 34(6), 303-311.

Chang, E., \& Hancock, K. (2003). Role stres and role ambiguity in new nursing graduates in Australia. Nursing \& Health Sciences, 5 (2), 155-163.

Clark, T., \& Holmes, S. (2007). Fit for practice? An exploration of the development of newly qualified nurses using focus groups. International Journal of Nursing Studies, 44, 1210-1220.

Cooper,A.M. \& Palmer,A.(2000). Mentoring, preceptorship and clinical supervision: $A$ guide to professional roles in clinical practice (2nd ed.). London: Blackwell Science.

Dubrin, A. J. \& Geerinck, T. (2009). Human relations: Interpersonal job oriented skills (3rd ed.). Toronto, ON, Canada: Pearson Education Canada Inc.
Duchscher, J.B. (2008). Transition shock: The initial stage of role adaptation for newly graduted registered nurses. Journal of Advanced Nursing. doi:10.1111/j.13652648.2008.04898.x.

Dumas, L., Villeneuve, J., \& Chevrier, J. (2000). A tool to evaluate how to learn from experience in clinical settings. Journal of Nursing Education, 39, 252-258.

Eley, S. M. (2010). The power of preceptorship. Diakses dari http://www.rnjournal.com/ journal_of_nursing/the_power_of_ preceptorship_2.htm.

Floyd, J.P. (2003). How nurse preceptors influence new graduates. Critical Care Nurse, 26, S52-S59.

Folkman, S. \& Lazarus, R.S. (1994) Ways of coping questionnaire manual test booklet, scoring key. Consulting Psychologist Press.

Gerrish, K. (2000). Still fumbling along? A comparative study of the newly qualified nurse $\mathrm{s}$ s perception of the transition from student to qualified nurse. Journal of Advanced Nursing, 32(2), 473-480.

Gillies, D. A. (1994). Nursing management a system approach (3rd ed.). Philadelphia: W.B. Saunders Company.

Hollenbeck, G. P., \& Hall, D.T. (2004). Self confidence \& leader performance. Organizational Dynamics 3, 261-264.

Health and Safety Executive (HSE). (2004). Stres-related and psychological disorders. Health and Safety Executive.

Kramer, M. (1974). Reality shock: why nurses leave nursing. St .Louis, MO: C.V. Mosby.

Mamchur, C., \& Myrick, F. (2003). Preceptorship and interpersonal conflict: a multidiciplinary study. A Journal of Advance Nursing, 43(2), 188-196.

Marquis, B. L., \& Houston, C. J. (2010). Leadership roles and management function in nursing: Theory and application, (5th ed.). 
Sr Sofia Gusnia: Hubungan Karekteristik Perawat pada Program Preceptorship

California: Lippincott Williams \& Wilkins. Myrick, F. \& Yonge, O. (2005). Nursing preceptorship connecting practice and education. Philadelphia: Lippincott Williams $\&$ Wilkins.

O’Brien-Pallas, L. I. N. D. A., Duffield, C., $\&$ Hayes, L. (2006). Do we really understand how to retain nurses?. Journal of Nursing Management, 14(4), 262-270.

O'Shea, M. \& Kelly, B. (2007). The lived experiences of newly qualified nurses on clinical placement during the first six months following registration in the Republic of Ireland. Journal of Clinical Nursing, 16, 1534-1542.

Peterson, J.Z. (2009). Dissertation: Job stres, job satisfaction and intention to leave among new nurses. (Unpublished Graduate Department of Nursing Science University of Toronto).

Rose, S. (2007). A guide to nursing preceptorship : High secure services ashworth hospital. Mersey Care.

Salt, J., Cummings, G., \& Profetto-McGrath, J. (2008). Increasing retention of new graduate nurses: A systematic review of interventions. The Journal of Nursing Administration, 287296.

Sopiah. (2008). Perilaku organisasional. Yogyakarta: CV Andi Offset.

Wang, S. H., Sermsri, S., Sirisook, V., \& Sawangdee, Y. (2003). Job satisfaction of staff nurses and their perception on head nurses' leadership: A study in Sakaeo provincial 